\title{
Changes in the blood indicators and body condition of high yielding Holstein cows with retained placenta and ketosis
}

\author{
Zenon Nogalski, Marek Wroński, Beata Lewandowska, Paulina Pogorzelska \\ University of Warmia and Mazury in Olsztyn, Department of Cattle Breeding and Milk Quality Evaluation, \\ Olsztyn, Poland
}

Received March 9, 2012

Accepted July 16, 2012

\begin{abstract}
The aim of this study was to determine the effect of changes in body condition in the dry period and the early lactation period on the incidence of retained placenta and ketosis in 94 highyielding Holstein-Friesian cows. Body condition scoring was performed every two weeks from the beginning of the dry period until week 18 of lactation. Blood for the measuring of indicators of metabolism was sampled in weeks 1 and 2 ante partum and in weeks 1, 2, 3, 7 and 15 post partum. Retained placenta was reported in 11 cows, and ketosis was diagnosed in 18 animals. One week ante partum, the serum profile of cows diagnosed with ketosis during lactation revealed $0.52 \mathrm{mmol} / 1 \beta$-hydroxybutyric acid and $0.29 \mathrm{mmol} / 1$ non-esterified fatty acids on average. One week post partum, the serum profile of cows with ketosis revealed $1.59 \mathrm{mmol} / 1 \beta$-hydroxybutyric acid and $1.09 \mathrm{mmol} / \mathrm{l}$ non-esterified fatty acids and cows with retained placenta 1.65 and 1.41 , respectively. From the week 5 ante partum to the point of lowest body condition the average body condition loss reached 1.4 points in cows with retained placenta, 1.1 points in cows with ketosis, and 0.8 points in healthy cows. Retained placenta and ketosis increased significantly conception rates by 0.47 and 0.50 , respectively. Our results show that monitoring changes in the body condition and non-esterified fatty acids and $\beta$-hydroxybutyric acid blood levels in highyielding cows in the transition period, followed by taking relevant disease-control measures, may be effective in reducing the incidence of retained placenta and ketosis in dairy cattle herds.
\end{abstract}

Dairy cows, body condition loss, serum metabolite, postpartum disease, reproductive performance

Disease prevention and maintenance of adequate production levels are the greatest challenges in high-yielding dairy herds during transition from the late dry period to the first weeks of lactation. In around $75 \%$ of cases, diseases affecting dairy cows are reported in the first month after calving (LeBlanc et al. 2006). The above mentioned can be attributed to a negative energy balance in the discussed period (Kim and Suh 2003). A significant drop in the feed intake is observed on pre-calving days (Hayirli et al. 2002). A negative energy balance causes metabolic stress which intensifies health disorders, including retained placenta that generates significant financial losses in dairy cattle herds due to high treatment costs, complications, milk loss, culling for infertility and increased mortality (Fleischer et al. 2001; Goff 2006). Ketosis is a frequent disease in high-yielding cows. It occurs when adipose tissue is used to meet energy demands and when non-esterified fatty acids (NEFA) are incompletely oxidized into ketone bodies.

Blood indicators and the body condition score (BCS) are good indicators of animals' nutritional and health status, and they are useful predictors of disease (Kaczmarowski et al. 2006). Early detection of cows prone to diseases, followed by modification of their diet and individual handling, may help reduce disease incidence. The indicators that are used to monitor imbalances in energy metabolism include glucose, NEFAs and betahydroxybutyrate (BHBA) (Ingvartsen et al. 2003). Elevated precalving cholesterol and NEFAs are associated with greater risk of retained placenta (LeBlanc et al. 2006). The body condition score and its variations are widely used to evaluate body reserves and the energy balance in cows. Gillund et al. (2001) observed that body condition loss during early lactation had negative effects on reproductive performance, while no such 
correlations were reported in other studies (Ruegg and Milton 1995; Heuer et al. 1999). Previous research studies have attempted to evaluate the effect of body condition at calving and changes therein during early lactation on the productivity, reproductive performance and health status of cows (Nogalski and Górak 2008). In view of the above, it seems interesting to analyze the influence of changes in the body condition of high-producing cows observed in the drying-off period on the overall health of animals.

The aim of this study was to investigate the associations between the incidence of retained placenta and ketosis in high-yielding dairy cows and body condition and blood profiles in the periparturient period and early lactation, and to determine whether changes in the body condition and blood indicators may help to detect cows particularly vulnerable to the above diseases.

\section{Materials and Methods}

Animals

A total of 94 animals from a herd of 330 Holstein-Friesian cows were selected for the experiment based on the following criteria: a similar calving date to eliminate the effect of calving season (the selected cows calved between 11 December 2007 and 14 March 2008), milk yield during the previous lactation (not lower than $10,000 \mathrm{~kg}$ of milk during 305-day lactation, for heifers milk yield was estimated based on pedigree information), lactation number proportionally for the entire herd (first lactation, second lactation, third lactation and fourth lactation with $25,30,24$ and 15 cows, respectively). A herd of cows kept in a free-stall system was investigated in this experiment. The animals were fed a total mixed ration (TMR) based on maize silage, grass and alfalfa haylage, and brewer's spent grain. In the complete diet, the concentrate was supplemented with protein, minerals, vitamins and milk production enhancers (protein and rumen-protected fat, active yeast cultures and other energy supplements). Cows were fed a TMR formulated to produce 401 of milk $(7.15 \mathrm{MJ} / \mathrm{kg}$ net energy (lactation) and $18 \%$ crude protein). Dry cows and heifers on pre-calving days 60-45 were kept in deep litter free-stall facilities, and they were divided into two groups: 1) dry cows: 6-8 weeks a.p. (ante partum) to 3 weeks a.p., 2) transition cows: 3 weeks a.p. to 1 week p.p. (post partum). Dry cows were fed a TMR of grass and straw haylage supplemented with minerals in the dry period. Transition cows were administered lactation rations with an increasing share of concentrate. Feed was offered twice daily, using mixer wagons, and it was gathered up several times per day to ensure ad libitum access.

\section{Study design and measurements}

Energy reserves were estimated based on the body condition scoring (BCS) scale of 1 (thin) to 5 (obese) points with 0.25 intervals (Wildman et al. 1982). Evaluations were performed every two weeks, starting from 5 weeks a.p. to 20 weeks p.p. Blood was sampled from the external jugular vein before the morning feeding at 2 and 1 weeks a.p., and at 1, 2, 3, 7 and 15 weeks p.p. Whole blood samples were analyzed to determine glucose levels as well as plasma concentrations of $\beta$-hydroxybutyric acid (BHBA), non-esterified fatty acids (NEFA), albumins and aspartate aminotransferase (AST) activity. Blood tests were performed using BioSystem diagnostic kits, the Roche Hitachi 902 chemistry analyzer and the EPOLL-200 spectrophotometer. Milk yield and reproductive performance data were obtained from breeding records, Symlek system as well as based on direct observations. Energy corrected milk (ECM) and the average content of fat, protein and dry matter per kg ECM were determined for each cow during 305-day lactation.

Energy Corrected Milk, milk with standardized energy content (Sjaunja et al. 1990), was calculated based on this formula:

$E C M(\mathrm{~kg})=\operatorname{milk}(\mathrm{kg}) \cdot \frac{(0.383 \cdot \operatorname{fat}(\%)+0.242 \cdot \operatorname{protein}(\%)+0.7832)}{3.140}$

Reproductive performance was determined by calculating the conception rate (CR, total inseminations/number of in-calf cows) and the inter-pregnancy interval (IPI, number of days between calving and successive conception).

In the herd, regular health examinations were performed by the same investigator once a week. Retained placenta was noted in 11 cows, and the clinical symptoms of primary ketosis were diagnosed in 18 animals. Retained placenta (RP) was defined as the retention of the foetal membrane for $>24 \mathrm{~h}$. Ketosis (K) was diagnosed based on the following clinical symptoms: anorexia, depression and odor of acetone on the breath.

Animal handling and sampling procedures performed for the needs of this study have been fully approved by the local ethics committee in Olsztyn, Poland.

Statistical analysis

In order to compare the indicators of RP and K cows, a control group (C) of 12 cows free of the analyzed disorders was selected by the analog method. The results were processed using Statistica 9.0 software (Statsoft 2010). The effect of the analyzed disorders on blood indicators, milk yield and reproductive performance was evaluated by the least squares analysis of variance according to the below model: 
$Y_{i j}=m+A_{i}+e_{i j}$

where: $Y_{i j}$ - values of the analyzed indicators, $m$ - population mean, $A_{i}-$ effect of the $i^{\text {th }}$ disorder, $e_{i j}-$ random error.

Differences between means were estimated using Tukey's test at the level of significance $P \leq 0.01$ and $P \leq 0.05$.

\section{Results}

The depth and length of the negative energy balance phase is illustrated by changes in BCS profile (Fig. 1). The lowest BCS values were noted in cows between weeks 5-7 of lactation. The energy demand and dietary energy intake were balanced at the turn of the second and third month of lactation. Between 5 weeks a.p. to the point of lowest BCS, the body condition of RP group cows deteriorated by 1.4 points, K group cows by 1.1 points, and control group cows by 0.8 points. The body condition of RP and K group cows in the dry period was higher in comparison with control group cows, and intense mobilization of fat reserves in the affected animals began already at the end of the dry period.

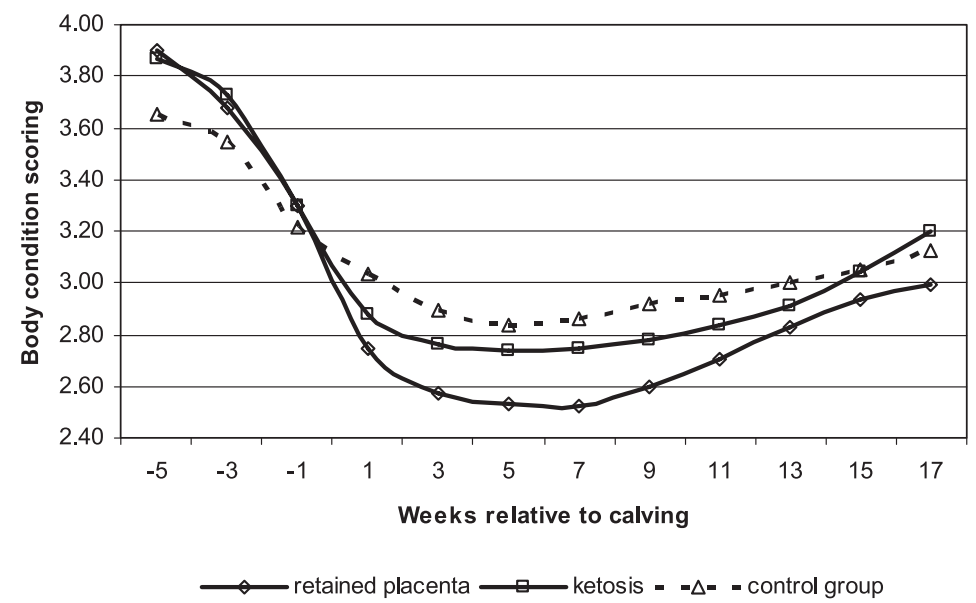

Fig. 1. Changes in body condition of cows in the dry period and the early lactation period

Significant differences in blood indicators indicative of metabolic changes were not reported in cows prior to calving (Table 1). In the first week a.p., the blood serum profile of cows diagnosed with ketosis during lactation revealed an average of $0.52 \mathrm{mmol} / \mathrm{l} \mathrm{BHBA}$ and $0.29 \mathrm{mmol} / 1 \mathrm{NEFA}$. In the second week p.p., K group animals were characterized by significantly lower glucose levels and significantly higher concentrations of BHBA and NEFAs in comparison with the remaining groups. In the RP group, high levels of ketone bodies and NEFA were observed only in the first week of lactation. In affected cows, blood cholesterol levels were significantly $(P \leq 0.05)$ lower at the beginning of lactation. At the beginning of lactation, significant $(P \leq 0.05)$ differences were reported in AST activity and albumin levels. In the second week p.p., AST levels in K group cows reached $218 \mathrm{U} / 1$ on average. In the third week p.p., albumin levels in diseased cows were lower $(P \leq 0.50)$ in comparison with healthy animals.

The yield of RP cows was by $808 \mathrm{~kg}$ ECM lower on average, in comparison with control group cows (Table 2). Retained placenta and ketosis had a negative effect of the reproductive performance of cows. Retained placenta and ketosis group animals were characterized 
Table 1. Selected indicators of metabolism (mean \pm SE) in cows with retained placenta $(n=11)$, ketosis $(n=18)$ and in the control group $(\mathrm{n}=10)$

\begin{tabular}{|c|c|c|c|c|c|c|c|c|}
\hline \multirow{2}{*}{ Indicator } & \multicolumn{8}{|c|}{ Weeks relative to calving } \\
\hline & Group & -2 & -1 & 1 & 2 & 3 & 7 & 15 \\
\hline \multirow[t]{3}{*}{ Glucose (mmol/l) } & RP & $4.15 \pm 0.12$ & $4.04 \pm 0.12$ & $3.20 \pm 0.12$ & $3.45 \pm 0.24^{\mathrm{a}}$ & $3.51 \pm 0.29$ & $3.59 \pm 0.14$ & $3.47 \pm 0.12$ \\
\hline & $\mathrm{K}$ & $3.85 \pm 0.23$ & $3.78 \pm 0.13$ & $3.23 \pm 0.23$ & $3.03 \pm 0.34^{b}$ & $3.11 \pm 0.25$ & $3.42 \pm 0.08$ & $3.43 \pm 0.13$ \\
\hline & $\mathrm{C}$ & $4.22 \pm 0.09$ & $4.23 \pm 0.24$ & $3.46 \pm 0.11$ & $3.46 \pm 0.09^{\mathrm{a}}$ & $3.48 \pm 0.12$ & $3.58 \pm 0.09$ & $3.49 \pm 0.11$ \\
\hline \multirow[t]{3}{*}{$\mathrm{BHBA}(\mathrm{mmol} / \mathrm{l})$} & $\mathrm{RP}$ & $0.42 \pm 0.03$ & $0.49 \pm 0.07$ & $1.65 \pm 0.21^{\mathrm{a}}$ & $0.93 \pm 0.36^{\mathrm{A}}$ & $0.77 \pm 0.33^{\mathrm{a}}$ & $0.59 \pm 0.09$ & $0.79 \pm 0.13$ \\
\hline & $\mathrm{K}$ & $0.44 \pm 0.04$ & $0.52 \pm 0.08$ & $1.59 \pm 0.21^{\mathrm{a}}$ & $2.43 \pm 0.37^{\mathrm{B}}$ & $1.18 \pm 0.34^{b}$ & $0.76 \pm 0.10$ & $0.66 \pm 0.14$ \\
\hline & $\mathrm{C}$ & $0.39 \pm 0.05$ & $0.33 \pm 0.08$ & $0.75 \pm 0.12^{\mathrm{b}}$ & $0.81 \pm 0.23^{\mathrm{A}}$ & $0.72 \pm 0.21^{\mathrm{a}}$ & $0.53 \pm 0.14$ & $0.64 \pm 0.06$ \\
\hline \multirow[t]{3}{*}{$\mathrm{NEFA}(\mathrm{mmol} / \mathrm{l})$} & $\mathrm{RP}$ & $0.19 \pm 0.04$ & $0.22 \pm 0.07$ & $1.41 \pm 0.27^{\mathrm{a}}$ & $0.92 \pm 0.31$ & $0.44 \pm 0.09^{\mathrm{a}}$ & $0.21 \pm 0.07$ & $0.14 \pm 0.04$ \\
\hline & K & $0.15 \pm 0.05$ & $0.29 \pm 0.08$ & $1.09 \pm 0.27^{\mathrm{a}}$ & $1.12 \pm 0.32^{\mathrm{A}}$ & $0.73 \pm 0.10^{b}$ & $0.31 \pm 0.08$ & $0.20 \pm 0.05$ \\
\hline & $\mathrm{C}$ & $0.12 \pm 0.02$ & $0.16 \pm 0.08$ & $0.78 \pm 0.07^{\mathrm{b}}$ & $0.69 \pm 0.13^{\mathrm{B}}$ & $0.41 \pm 0.13^{\mathrm{a}}$ & $0.16 \pm 0.05$ & $0.19 \pm 0.02$ \\
\hline \multirow[t]{3}{*}{ Cholesterol (mmol/l) } & RP & $2.34 \pm 0.09$ & $2.23 \pm 0.13$ & $2.34 \pm 0.11$ & $3.20 \pm 0.35^{\mathrm{a}}$ & $3.49 \pm 0.41^{\mathrm{A}}$ & $5.68 \pm 0.27^{\mathrm{a}}$ & $7.82 \pm 0.21$ \\
\hline & K & $2.32 \pm 0.10$ & $2.25 \pm 0.14$ & $2.30 \pm 0.12$ & $2.26 \pm 0.26^{b}$ & $3.42 \pm 0.41^{\mathrm{A}}$ & $6.26 \pm 0.27^{\mathrm{a}}$ & $8.02 \pm 0.22$ \\
\hline & $\mathrm{C}$ & $2.53 \pm 0.14$ & $2.43 \pm 0.19$ & $2.48 \pm 0.23$ & $3.08 \pm 0.24^{\mathrm{a}}$ & $4.94 \pm 0.27^{\mathrm{B}}$ & $7.11 \pm 0.21^{b}$ & $7.49 \pm 0.34$ \\
\hline \multirow[t]{3}{*}{ Ast (U/l) } & RP & $84.0 \pm 8.19$ & $69.5 \pm 8.49$ & $127.0 \pm 7.99$ & $142.0 \pm 9.89^{\mathrm{a}}$ & $96.8 \pm 9.43$ & $84.0 \pm 6.56$ & $91.1 \pm 4.53$ \\
\hline & K & $92.5 \pm 5.69$ & $73.0 \pm 5.52$ & $126.8 \pm 7.10$ & $218.0 \pm 9.90^{\mathrm{b}}$ & $115.4 \pm 9.44$ & $98.1 \pm 6.57$ & $99.3 \pm 4.54$ \\
\hline & $\mathrm{C}$ & $77.0 \pm 5.37$ & $88.2 \pm 11.04$ & $130,7 \pm 9.81$ & $166.2 \pm 8.09^{\mathrm{a}}$ & $113.6 \pm 8.92$ & $91.4 \pm 8.57$ & $102.2 \pm 8.58$ \\
\hline \multirow[t]{3}{*}{ Albumins (g/l) } & $\mathrm{RP}$ & $42.7 \pm 1.34$ & $40.7 \pm 0.47$ & $38.4 \pm 1.91$ & $34.3 \pm 2.84$ & $32.9 \pm 1.45^{\mathrm{a}}$ & $38.3 \pm 2.15$ & $41.5 \pm 1.26$ \\
\hline & K & $42.5 \pm 1.84$ & $41.0 \pm 0.48$ & $36.4 \pm 1.78$ & $38.4 \pm 2.03$ & $35.9 \pm 1.45^{\mathrm{a}}$ & $41.9 \pm 1.25$ & $42.7 \pm 1.27$ \\
\hline & $\mathrm{C}$ & $40.1 \pm 1.10$ & $38.7 \pm 1.34$ & $37.0 \pm 0.91$ & $37.6 \pm 0.91$ & $40.4 \pm 1.64^{b}$ & $41.5 \pm 1.09$ & $42.5 \pm 1.04$ \\
\hline
\end{tabular}

$\mathrm{RP}$ - retained placenta, $\mathrm{K}$ - ketosis, C - control group, BHBA - $\beta$-hydroxybutyric acid, NEFA - non-esterified fatty acids, Ast - aspartate aminotransferase

In columns: ${ }^{\mathrm{A}, \mathrm{B}}-P \leq 0.01{ }^{\mathrm{a}, \mathrm{b}}-P \leq 0.05$

Table 2. Milk yield and reproductive performance traits (mean $\pm \mathrm{SE}$ ) in cows with retained placenta, ketosis and in the control group.

\begin{tabular}{lccc}
\hline Traits & $\begin{array}{c}\text { Retained placenta } \\
(\mathrm{n}=11)\end{array}$ & $\begin{array}{c}\text { Ketosis } \\
(\mathrm{n}=18)\end{array}$ & $\begin{array}{c}\text { Control group } \\
(\mathrm{n}=10)\end{array}$ \\
\hline ECM (kg) & $12204 \pm 778.8$ & $13068 \pm 565.2$ & $13012 \pm 527.1$ \\
Fat (\%) & $4.32 \pm 0.16$ & $4.36 \pm 0.13$ & $4.18 \pm 0.10$ \\
Protein (\%) & $3.27 \pm 0.05$ & $3.19 \pm 0.06$ & $3.18 \pm 0.06$ \\
Dry weight (\%) & $13.06 \pm 0.18$ & $12.99 \pm 0.19$ & $12.80 \pm 0.13$ \\
CR & $2.28 \pm 0.22^{\mathrm{a}}$ & $2.31 \pm 0.16^{\mathrm{a}}$ & $1.81 \pm 0.16^{\mathrm{b}}$ \\
IPI & $135.1 \pm 19.23$ & $159.0 \pm 13.12$ & $118.6 \pm 11.19$ \\
\hline
\end{tabular}

ECM - Energy corrected milk, CR - conception rate, IPI - inter-pregnancy interval

In rows: ${ }^{\mathrm{a}, \mathrm{b}}-P \leq 0.05$

by a longer inter-pregnancy period and significantly higher $(P \leq 0.50)$ conception rates, compared to healthy cows.

\section{Discussion}

The optimal body condition score for dairy cows at calving is 3.5 (Nogalski and Górak 2008; Ruegg and Milton 1995). Deviations from the optimal score increase the risk of metabolic diseases and prevent the achievement of maximum milk yield values during lactation (Staufenbiel et al. 2003). Gillund et al. (2001) reported a doubling 
of the risk of ketosis in dairy cows with a calving BCS of $>3.5$ compared with those with a calving BCS of 3.25. Their findings are consistent with a comprehensive review of periparturient morbidity and its relationship to excessive BCS mobilization (Ingvartsen 2006). In our study, retained placenta or ketosis was observed in cows undergoing intense fat mobilization, in particular in the dry period. Due to a rapid drop in the feed intake, highproducing cows mobilize energy reserves already 1-3 weeks before calving. An analysis of NEFA profiles supports an evaluation of the rate of lypolysis which is negatively correlated with the energy balance (Ingvartsen 2006). Optimal content non-esterified fatty acids and $\beta$-hydroxybutyric acid in the blood serum of healthy cows is $0.5-0.7$ and $0.6-1.0 \mathrm{mmol} / \mathrm{l}$, respectively (Whitaker et al. 2005). In our study, K and RP group cows characterized by higher body condition scores intensively mobilized their body fat reserves before calving, and the above resulted in higher NEFA and BHBA levels in their blood serum. Elevated precalving NEFA concentrations could, therefore, be a predictor of increased risk of retained placenta and ketosis. In the first week a.p., higher NEFA concentrations were observed in cows that had been diagnosed with ketosis during early lactation. Aspartate aminotransferase is responsible for protein balance, and this cytoplasmatic enzyme is a labile and sensitive indicator of changes in liver metabolism resulting from high productivity. In our study, RP and K group cows showed very high AST activity levels. The AST activity of cows affected by ketosis exceeded $200 \mathrm{U} / \mathrm{l}$ in the second week p.p., and the above results could be indicative of hepatic cell damage (Meikle et al. 2004). Ketosis was observed mainly in cows in their first and second lactation. Young animals, in particular primiparous cows, are characterized by more unbalanced metabolic and endocrinological profiles than older cows, which is why they emerge from the NEB state with greater difficulty.

Lower reproductive performance in groups $\mathrm{K}$ and RP could result from a high energy deficit in transition cows. High energy deficits in early lactation delayed the first detected oestrus (De Vries et al. 1999). Kim and Suh (2003) demonstrated that Holstein dairy cows with greater body condition loss in the dry period were characterized by a higher incidence of post partum metabolic diseases and a longer calving to first service interval. Walsh et al. (2007) noted significantly lower insemination effectiveness in cows with elevated levels of ketone bodies in the first weeks of lactation. The reproductive performance of cows should also be evaluated in view of their high productivity. For decades, Holstein-Friesian cows have been subject to intensive selection for increased milk yield. As a result, cows with inherited weaker body condition naturally prolong the post partum interval to stall successive pregnancies (Dechow et al. 2002). An energy deficit stimulated the release of reserve fat, and it increased milk fat synthesis in the udder, as noted in the group of cows with ketosis. Fat reserves were mobilized more readily by diseased cows, and the above should enhance productivity. In a German study, the milk yield of cows that mobilized subcutaneous fat (10-12 mm) most intensively was more than $2,000 \mathrm{~kg}$ higher on average than in the group of cows mobilizing 6-7 mm of fat (Staufenbiel et al. 2003). Significant correlations were not determined between disease incidence and milk yield, in particular as regards ketosis. It should be noted, however, that ketosis affects highest-yielding cows; therefore, productivity results were levelled out by the disease.

Overconditioning of dry cows and rapid fat mobilization in the transition period predisposes cows to an increased risk of metabolic disorders and lowers their reproductive performance. Maximizing feed intake in early lactation is therefore a primary goal to prevent metabolic diseases, such as ketosis. Our results show that monitoring changes in the body condition and NEFA and BHBA blood levels in high-yielding cows in the transition period, followed by taking relevant disease-control measures, may be effective in reducing the incidence of retained placenta and ketosis in dairy cattle herds. 


\section{References}

Dechow CD, Rogers GW, Clay JS 2002: Heritability and correlations among body condition score loss, body condition score, production and reproductive performance. J Dairy Sci 85: 3062-3070

de Vries MJ, van der Beek S, Kaal-Lansbergen LMTE, Ouweltjes W, Wilmink JBM 1999: Modeling of energy balance in early lactation and the effect of energy deficits in early lactation on first detected estrus postpartum in dairy cows. J Dairy Sci 82: 1927-1934

Fleischer P, Metzner M, Hoedemaker M, Šlosárková S, Skřivánek M 2001: Clinical disorders in Holstein cows: Incidence and associations among lactational risks factors. Acta Vet Brno 70: 157-165

Gillund P, Reksen O, Grohn YT, Karlberg K 2001: Body condition related to ketosis and reproductive performance in Norwegian dairy cows. J Dairy Sci 84: 1390-1396

Goff JP 2006: Major advances in our understanding of nutritional influence on bovine health. J Dairy Sci 89: 1292-1301

Hayirli A, Grummer RR, Nordheim EV, Crump PM 2002: Animal and dietary factors affecting feed intake during the prefresh transition period in Holsteins. J Dairy Sci 85: 3430-3443

Heuer C, Schukken YH, Dobbelaar P 1999: Postpartum body condition score and results from the first test day milk as predictors of disease, fertility, yield, and culling in commercial dairy herds. J Dairy Sci 82: 295-304

Ingvartsen KL 2006: Feeding- and management-related disease in the transition cow: Physiological adaptation around calving and strategies to reduce feeding-related diseases. Anim Feed Sci Technol 126: 175-213

Ingvartsen KL, Dewhurst RJ, Friggens NC 2003: On the relationship between lactational performance and health: is it yield or metabolic imbalance that cause production diseases in dairy cattle? A position paper. Liv Prod Sci 83: $277-308$

Kaczmarowski M, Malinowski E, Markiewicz H 2006: Some hormonal and biochemical blood indices in cows with retained placenta and puerperal metritis. Bull Vet Ins Pulawy 50: 89-92

Kim IH, Suh GH 2003: Effect of the amount of body condition loss from the dry to near calving periods on the subsequent body condition change, occurrence of postpartum diseases, metabolic parameters and reproductive performance in Holstein dairy cows. Theriogenology 60: 1445-1456

LeBlanc SJ, Lissemore KD, Kelton DF, Duffield TF, Leslie KE 2006: Major advances in disease prevention in dairy cattle. J Dairy Sci 89: 1267-1279

Meikle A, Kulcsar M, Chilliard Y, Febel H, Delavaud C, Cavestany D, Chilibroste P 2004: Effects of parity and body condition at parturition on endocrine and reproductive parameters of the cow. Reproduction 127: 727-737

Nogalski Z, Górak E 2008: Effects of the body condition of heifers at calving and at the first stage of lactation on milk performance. Medycyna Wet 64: 322-326

Ruegg PL, Milton RL 1995: Body condition scores of Holstein cows on Prince Edward Island, Canada: relationships with yield, reproductive performance, and disease. J Dairy Sci 78: 552-564

Sjaunja LO, Baevre B, Junkkarinen L, Pedersen J, Setala J 1990: A Nordic proposal for an energy corrected milk (ECM) formula. EAAP Publication 50: 156-157

Staufenbiel R, Schröder U, Gelert CC, Panicke L 2003: Body condition and metabolic stability as basis of high milk yield, reproductive performance, and general health in dairy cows (in German) Arch Tierz 46: 513-526

Walsh RB, Walton JS, Kelton DF, LeBlanc SJ, Leslie KE, Duffield TF 2007: The effect of subclinical ketosis in early lactation on reproductive performance of postpartum dairy cows. J Dairy Sci 90: 2788-2796

Whitaker DA 1997: Interpretation of metabolic profiles in dairy cows. Cattle Practice 5: 57 - 60

Wildman EE, Jones GM, Wagner PE, Boman RL, Troutt HF, Lesch TN 1982: A dairy cow body condition scoring system and its relationship to selected production characteristics. J Dairy Sci 65: 495-501 